\title{
Corn Variety Trials on a Eutrustox in Puerto Rico ${ }^{1,2}$
}

\author{
G. L. Spain, S. P. Nightengale and J. Badillo-Feliciano ${ }^{3}$
}

ABSTRACT

\begin{abstract}
Four corn (Zea mays L.) variety trials were conducted during 1976-78 at the Isabela Agricultural Experiment Substation near the northwest coast of Puerto Rico. The Pioneer brand hybrid X304C ranked highest in three experiments with yields of $9,782,3,962$ and $8,998 \mathrm{~kg} / \mathrm{ha}$ of $15.5 \%$-moisture grain, and was second only to $\times 5800(6,559 \mathrm{~kg} / \mathrm{ha})$ in a fourth trial with $5,856 \mathrm{~kg} /$ ha. Other leading hybrids were X304A, Х304B, Х306B, X105A, H638 and H652. While certain hybrids and local open pollinated varieties yielded significantly less, grain yields among the top ranked entries in each experiment were not significantly different.
\end{abstract}

\section{INTRODUCTION}

Innovative studies to test and demonstrate the transfer of agricultural technology from one tropical area to another on the basis of soil classification were initiated in 1975 by the University of Hawaii (UH) and the University of Puerto Rico (UPR). The two studies are collectively known as the Benchmark Soils Project (BSP). The rationale of the agrotechnology transfer concept and the BSP is discussed by Beinroth et al. (2) and in greater detail in BSP Progress Reports 1 and $2(3,4)$.

A standard test-crop was essential for use throughout the network of BSP experiments. Corn was selected, since it is one of the most important and widely adapted food crops in the developing world and because a wealth of fundamental knowledge relative to its production is already available for application. Requirements of the test-crop variety are that it be well adapted to the experiment locations, and that it be responsive to management inputs, and yield well.

In the past, open pollinated varieties such as Diente de Caballo and Mayorbela were commonly planted in Puerto Rico. These two cultivars are still grown, but recently higher grain yields have been reported for various commercial hybrids which respond well to more intensive management. Fox et al. (6) obtained grain yields during the summer of 1970 from Pioneer brand hybrid X306 ranging from 1,700 to 5,100 kg/ha with 0 to $134 \mathrm{~kg} / \mathrm{ha}$ of $\mathrm{N}$ applied in experiments conducted on a Coto clay (Tropeptic Eutrustox) at Isabela, Puerto Rico; they also reported yields

\footnotetext{
${ }^{1}$ Manuscript submitted to Editorial Board December 1, 1980.

${ }^{2}$ This study was part of the investigations supported by research contract AID-ta-c-1158.

${ }^{3}$ Agronomist, Assistant Agronomist, and Agronomist, Agricultural Experiment Station, University of Puerto Rico, Mayagüez Campus, Puerto Rico, respectively. Luis Calduch, former Research Assistant, participated in the field experiments.
} 
up to $6,300 \mathrm{~kg} / \mathrm{ha}$ for the same season on a Catalina clay (Tropeptic Haplorthox) at Barranquitas in the interior uplands of the island. Later, $\mathrm{X} 306 \mathrm{~B}$ and hybrid Funks G 795W produced up to 6,100 and $5,000 \mathrm{~kg} / \mathrm{ha}$, respectively, on a Bayamón sandy loam (Typic Haplorthox), but G795W was damaged by leaf blight and earworms (11). Talleyrand et al. (10) recorded that the same hybrid, G795W, yielded $5,400 \mathrm{~kg} / \mathrm{ha}$ of grain on the Bayamón sandy loam (irrigated) with $200 \mathrm{~kg} / \mathrm{ha}$ of $\mathrm{N}$, and $3,800 \mathrm{~kg} /$ ha on the Catalina clay (unirrigated) with no response to applied N. In an experiment with 7 cultivars on a Coto clay at Isabela, Badillo-Feliciano et al. (1) obtained grain yields ranging from 4,828 to $8,237 \mathrm{~kg} / \mathrm{ha}$. Pioneer's X306B ranked highest, followed by Diente de Caballo with $7,387 \mathrm{~kg} / \mathrm{ha}$. Mayorbela and G795W were less productive. Timing of the $\mathrm{N}$ application was more important than the amount applied, with the best results when $\mathrm{N}$ was applied 1 month after planting.

Sotomayor-Rios (9) conducted field trials with 12 corn entries on a Coto clay at Isabela and reported first-crop yields of the top 5 entries of $5,975,5,734,5,593,5,331$ and $5,223 \mathrm{~kg} / \mathrm{ha}$ of $15.5 \%$-moisture grain for Pioneer hybrids X304C, X306B, X105A, Dekalb hybrid B666, and open pollinated variety Diente de Caballo, respectively. Second and third crops of the same entries were planted on the same land to complete one full year of cropping. After the first crop, yields diminished slightly, fewer yield differences were significant, and ranking of the top entries changed somewhat for the succeeding two crops, probably because of seasonal effect.

The variety trials described herein were conducted for three years during both so-called wet and dry seasons at Isabela, Puerto Rico. The primary purpose of these experiments was to select a variety responsive to management inputs and well adapted to the soil family of clayey, kaolinitic, isohyperthermic Tropeptic Eutrustox, and climatic conditions prevailing in a network of UPR-BSP experiment sites.

\section{MATERIALS AND METHODS}

Hybrids and open pollinated varieties that had appeared well adapted to local conditions were selected for further study. In addition, available cultivars selected from those showing the best performance in the CIMMYT International Maize Adaptation Nursery (IMAN) 1970-71 (5), at elevations and latitudes similar to those of UPR-BSP, sites were included in the BSP variety trials at Isabela. Other cultivars recommended by cooperators were also included.

The experiments were conducted at the Isabela Agricultural Experiment Substation in northwestern Puerto Rico at $128 \mathrm{~m}$ above sea level and at lat. $18^{\circ} 28^{\prime} \mathrm{N}$, where the mean annual minimum and maximum air temperatures are $18.9^{\circ}$ and $29.4^{\circ} \mathrm{C}$, respectively, and mean annual rainfall 
is $1,658 \mathrm{~mm}$. The soil at the Substation is predominantly Coto clay with some Cotito clay at some sites. Both soils are classified as Tropeptic Eutrustox; clayey, kaolinitic, isohyperthermic. Surface soil pH ranged from 5.2 to 6.8 in the areas used. Table 1 shows weather data recorded during each experiment.

Four experiments were conducted during the following periods: May 14 to August 30, 1976; June 17 to October 4, 1977; December 13, 1977, to April 18, 1978; and April 26 to August 10, 1978. Maize varieties planted in each experiment are listed in tables $2,3,4$ and 5 . In the first two experiments, 16 varieties were tested at two levels of $\mathrm{P}$ : approximately .01 (P.01) and .05 (P.05) p/m P in the soil solution. For the third trial, seven varieties were grown at the two levels of $P$, and in the fourth, eight varieties were tested at both P-levels plus 2 levels of N, 90 and $166 \mathrm{~kg} / \mathrm{ha}$. Phosphorus levels were determined and adjusted according to the method of Fox and Kamprath (7). Phosphorus applied was triple superphosphate, and the $\mathrm{N}$ source was ammonium sulfate.

In all experiments, a split-plot design was used. Phosphorus levels were assigned to main plots, and varieties to sub-plots. For the fourth experiment, $\mathrm{N}$ treatments were randomly assigned to sub-sub-plots. Experiments 1, 2 and 4 were all conducted on the same plots; thus, phosphorus treatments were randomly assigned for only the first experiment. Desired P-levels were attained in subsequent experiments by analyzing new soil samples and applying the required amounts of $\mathrm{P}$. Variety assignment was done randomly each time. The $\mathrm{N}$-level sub-sub-plots in the fourth experiment were made possible in the same area by halving the number of varieties tested.

A flat seedbed without furrows was plowed twice to a depth of approximately $25 \mathrm{~cm}$ and then disced and rototilled. All plots received a blanket application of $125,100,15$ and $2 \mathrm{~kg} / \mathrm{ha}$ of $\mathrm{K}, \mathrm{Mg}, \mathrm{Zn}$ and $\mathrm{B}$, respectively; nutrient sources were $\mathrm{KCl}, \mathrm{MgSO}_{4}, \mathrm{ZnSO}_{4}$ and borax. All plots in the

TABLE 1.-Mean daily rainfall, evaporation and solar radiation and the mean wind speed during corn variety trials 1, 2, 3 and 4 conducted at the Isabela Agricultural Experiment Substation, Isabela, Puerto Rico

\begin{tabular}{lcccc}
\hline \multirow{2}{*}{ Weather statistics } & \multicolumn{4}{c}{ Experiment No. } \\
\cline { 2 - 5 } & \multicolumn{1}{c}{1} & 2 & 3 & 4 \\
\hline Rainfall (mm/day) & 4.38 & 3.97 & 3.72 & 6.22 \\
Evaporation (mm/day) & 5.21 & 5.02 & 4.20 & 5.09 \\
Wind speed (km/hr) & 4.7 & 5.4 & 5.3 & 5.0 \\
Radiation (Ly/day) & 461 & 470 & 365 & 480 \\
Period (mo-day-yr) & $5-14$ to & $6-17$ to & $12-13-77$ to & $4-26$ to \\
& $8-30-76$ & $10-4-77$ & $4-18-78$ & $8-10-78$ \\
Duration (days) & 108 & 109 & 126 & 106 \\
\hline
\end{tabular}


TABLE 2.-Grain yield and other agronomic data for corn varieties in experiment 1 planted May 14 and harvested August 30,1976 (108 days) at Isabela, Puerto Rico

\begin{tabular}{|c|c|c|c|c|c|c|}
\hline Variety/Source & Lodging & Ear length & Ear weight & Shelling & Grain $^{2}$ & Stover DM \\
\hline & $\%$ & $\mathrm{~cm}$ & $g$ & $\%$ & $\mathrm{~kg} / \mathrm{ha}$ & $k g / h a$ \\
\hline X304C, Pioneer & $0.7 \mathrm{f}$ & $16.2 \mathrm{ab}$ & $268 \mathrm{ab}$ & 78 defg & 9782 a & $10200 \mathrm{ab}$ \\
\hline X304B, Pioneer & 4.3 ef & $15.1 \mathrm{bcd}$ & $262 \mathrm{abc}$ & 77 efgh & $8957 \mathrm{ab}$ & $8936 \mathrm{bc}$ \\
\hline X304A, Pioneer & 9.3 bcde & $15.5 \mathrm{bc}$ & 275 a & $74 \mathrm{~h}$ & 8349 bc & 8535 cde \\
\hline H638, Hawaii & 9.7 bede & $17.0 \mathrm{a}$ & 227 cdef & $82 \mathrm{bc}$ & $8315 \mathrm{bc}$ & $4351 \mathrm{i}$ \\
\hline X105A, Pioneer & 8.8 bcde & 14.5 cde & 237 bcd & 79 cdef & 8186 bcd & $7028 \mathrm{fg}$ \\
\hline H652, Hawaii & 7.5 bcde & $15.2 \mathrm{bc}$ & $191 \mathrm{fg}$ & $83 \mathrm{~b}$ & 8019 bcd & $4487 \mathrm{i}$ \\
\hline X306B, Pioneer & $11.3 \mathrm{abcd}$ & $13.6 \mathrm{e}$ & 246 abcd & $76 \mathrm{fgh}$ & 7687 cde & 8740 bed \\
\hline H788, Hawaii & $13.2 \mathrm{ab}$ & $15.2 \mathrm{bc}$ & 232 bcde & $75 \mathrm{gh}$ & 7659 cde & $6114 \mathrm{gh}$ \\
\hline UPCA-1, Phil. & $4.3 \mathrm{ef}$ & 14.5 cde & 210 defg & 79 cdef & 7238 cdef & 8626 cde \\
\hline H610, Hawaii & 5.2 def & 14.2 cde & $190 \mathrm{~g}$ & 79 cdef & 7094 def & $5297 \mathrm{hi}$ \\
\hline H507 INIA, Mex. & $12.3 \mathrm{abc}$ & 14.9 bcde & $249 \mathrm{abc}$ & $77 \mathrm{efgh}$ & 7059 def & $10473 \mathrm{a}$ \\
\hline H5, Honduras & $17.5 \mathrm{a}$ & 14.7 bcde & $236 \mathrm{bcd}$ & 78 defg & 7029 def & $7037 \mathrm{fg}$ \\
\hline Diente de Caballo, P.R. & 11.2 abcde & $15.7 \mathrm{abc}$ & 228 cdef & 80 bcde & 6966 def & 7370 defg \\
\hline Mayorbela, P. R. & 5.5 cdef & $15.7 \mathrm{abc}$ & $195 \mathrm{efg}$ & $75 \mathrm{gh}$ & 6672 ef & $6984 \mathrm{fg}$ \\
\hline D M R, Philippines & 5.3 def & 13.7 de & $191 \mathrm{fg}$ & $81 \mathrm{bcd}$ & $6402 \mathrm{f}$ & 7158 efg \\
\hline Oaxaca 179, Mex. & 5.7 cdef & $10.2 \mathrm{f}$ & $99 \mathrm{~h}$ & 89 a & $4670 \mathrm{~g}$ & $3882 \mathrm{i}$ \\
\hline
\end{tabular}

${ }^{1}$ In each column means followed by one or more letters in common do not differ significantly at the $5 \%$ probability level. Each value represents the mean of 6 plots ( 3 replicates and 2 levels of P).

${ }^{2}$ Adjusted to $15.5 \%$ moisture. 
TABLE 3.-Grain yield and other agronomic data for corn varieties in experiment 2 planted June 17 and harvested October 4, 1977 (109 days) at Isabela, Puerto Rico'

\begin{tabular}{|c|c|c|c|c|c|c|c|}
\hline \multirow{2}{*}{ Variety/Source } & \multirow{2}{*}{ Lodging } & \multirow{2}{*}{ Ear length } & \multicolumn{2}{|c|}{ Ear weight ${ }^{2}$} & \multirow{2}{*}{ Shelling } & \multirow{2}{*}{ Grain $^{3}$} & \multirow{2}{*}{ Stover DM } \\
\hline & & & P.05 & P. .01 & & & \\
\hline & $\%$ & $\mathrm{~cm}$ & $g$ & $g$ & $\%$ & $\mathrm{~kg} / \mathrm{ha}$ & $k g / h a$ \\
\hline X304C, Pioneer & $44.2 \mathrm{~cd}$ & $12.5 \mathrm{a}$ & $102 \mathrm{ab}$ & 125 abc & $78 \mathrm{a}$ & 3962 a & $10051 \mathrm{~cd}$ \\
\hline X304B, Pioneer & $51.0 \mathrm{c}$ & 11.4 abcde & $106 \mathrm{ab}$ & $100 \mathrm{cde}$ & $76 \mathrm{a}$ & $3647 \mathrm{ab}$ & 10374 bcde \\
\hline X306B, Pioneer & 41.3 cde & 10.6 cde & $99 \mathrm{ab}$ & $106 \mathrm{bcd}$ & $76 \mathrm{a}$ & $3388 \mathrm{abc}$ & 9134 def \\
\hline QK231, Australia & $15.5 \mathrm{f}$ & $10.2 \mathrm{ef}$ & $96 \mathrm{ab}$ & $133 \mathrm{ab}$ & $75 \mathrm{a}$ & 3264 bed & $13237 \mathrm{abc}$ \\
\hline S1973 Central Mex. Br. & $17.1 \mathrm{f}$ & $12.4 \mathrm{ab}$ & $105 \mathrm{ab}$ & 150 a & $72 \mathrm{a}$ & $3234 \mathrm{bcd}$ & 12006 abcde \\
\hline UPCA-1, Philippines & $43.3 \mathrm{~cd}$ & 11.4 abcde & $89 \mathrm{abc}$ & $93 \mathrm{de}$ & $78 \mathrm{a}$ & $3181 \mathrm{bcd}$ & 9650 def \\
\hline H638, Hawaii & $17.0 \mathrm{f}$ & $11.8 \mathrm{abc}$ & $106 \mathrm{ab}$ & 80 defg & $77 \mathrm{a}$ & 2970 cde & $13982 \mathrm{ab}$ \\
\hline QK217, Australia & $19.2 \mathrm{f}$ & 11.2 bcde & $107 \mathrm{a}$ & 129 abc & $71 \mathrm{a}$ & 2709 def & $14120 \mathrm{ab}$ \\
\hline H507, INIA, Mexico & 26.4 def & 11.5 abcd & 76 abcd & 104 bcde & $72 \mathrm{a}$ & 2478 ef & $13412 \mathrm{abc}$ \\
\hline IAC 1110 & $23.6 \mathrm{ef}$ & 11.2 bcde & $99 \mathrm{ab}$ & 76 defg & $75 \mathrm{a}$ & $2447 \mathrm{ef}$ & 12755 abcde \\
\hline IAC Maya X 1975 & 25.6 def & $12.4 \mathrm{ab}$ & $63 \mathrm{~cd}$ & 85 def & $73 \mathrm{a}$ & 2354 ef & 14471 a \\
\hline Ag 504, Agroceres, Br. & $53.2 \mathrm{c}$ & $11.5 \mathrm{abcd}$ & 60 cde & $59 \mathrm{fgh}$ & 79 a & $2168 \mathrm{f}$ & 8672 ef \\
\hline 111, Cargil, Br. & $55.6 \mathrm{bc}$ & $11.8 \mathrm{abc}$ & $73 \mathrm{bcd}$ & $72 \mathrm{efg}$ & $73 a$ & $2155 \mathrm{f}$ & 8786 ef \\
\hline Ag 259, Agroceres, Br. & $72.0 \mathrm{ab}$ & $10.4 \mathrm{de}$ & $49 \mathrm{de}$ & $37 \mathrm{~h}$ & $73 \mathrm{a}$ & $1229 \mathrm{~g}$ & 9280 def \\
\hline QK 487, Australia & $47.7 \mathrm{c}$ & $8.4 \mathrm{~g}$ & $51 \mathrm{de}$ & $51 \mathrm{gh}$ & $74 \mathrm{a}$ & $1217 \mathrm{~g}$ & 9354 def \\
\hline H 610, Hawaii & $88.8 \mathrm{a}$ & $9.2 \mathrm{fg}$ & $31 \mathrm{e}$ & $35 \mathrm{~h}$ & $62 \mathrm{~b}$ & $962 \mathrm{~g}$ & $6127 \mathrm{f}$ \\
\hline
\end{tabular}

${ }^{1}$ In each column, means followed by one or more letters in common do not differ significantly at the $5 \%$ probability level. Each value represents the mean of 6 plots (2 levels of $P$ and 3 replicates).

${ }^{2}$ Ear weight values are shown for P .05 and P .01 treatments separately. No other parameter reflected treatment $\times$ sub-treatment interactions.

${ }^{3}$ Adjusted to $15.5 \%$ moisture. 
TABLE 4.-Grain yield and other agronomic data for corn varieties in experiment 3 planted December 13, 1977, and harvested April 18, 1978 (126 days) at Isabela, Puerto Rico'

\begin{tabular}{|c|c|c|c|c|c|c|c|}
\hline Variety/Source & Lodging & Ear length & Ear weight & Shelling & 100-seed & Grain $^{2}$ & Stover DM \\
\hline & $\%$ & $\mathrm{~cm}$ & $g$ & $\%$ & g weight & $\mathrm{kg} / \mathrm{ha}$ & $\mathrm{kg} / \mathrm{ha}$ \\
\hline X304C, Pioneer & $2.9 \mathrm{c}$ & $13.4 \mathrm{ab}$ & $229 \mathrm{a}$ & $79 \mathrm{ab}$ & $44.0 \mathrm{~b}$ & 8998 a & $8423 \mathrm{ab}$ \\
\hline X304A, Pioneer & $4.3 \mathrm{bc}$ & $12.9 \mathrm{~b}$ & 225 a & $77 \mathrm{~cd}$ & $47.5 \mathrm{ab}$ & $8818 \mathrm{ab}$ & $8411 \mathrm{ab}$ \\
\hline X304B, Pioneer & $5.3 \mathrm{bc}$ & $11.8 \mathrm{c}$ & $205 \mathrm{ab}$ & $76 \mathrm{~d}$ & $45.0 \mathrm{~b}$ & 8184 abc & $8517 \mathrm{ab}$ \\
\hline X306B, Pioneer & $2.1 \mathrm{c}$ & $10.8 \mathrm{~d}$ & $208 \mathrm{ab}$ & $78 \mathrm{bc}$ & $48.1 \mathrm{ab}$ & 7796 abc & $9666 \mathrm{a}$ \\
\hline 111, Cargill, Br. & $5.4 \mathrm{bc}$ & $14.3 \mathrm{a}$ & $182 \mathrm{~b}$ & $79 \mathrm{ab}$ & $31.4 \mathrm{c}$ & $7520 \mathrm{bc}$ & $8474 \mathrm{ab}$ \\
\hline Diente de Caballo, P.R. & $14.4 \mathrm{a}$ & $14.0 \mathrm{a}$ & 225 a & $80 \mathrm{a}$ & $50.3 \mathrm{a}$ & $7081 \mathrm{c}$ & $7295 \mathrm{~b}$ \\
\hline H610, Hawaii & $10.3 \mathrm{ab}$ & $9.9 \mathrm{e}$ & $123 \mathrm{c}$ & $78 \mathrm{bc}$ & $34.0 \mathrm{c}$ & $5036 \mathrm{~d}$ & $3936 c$ \\
\hline
\end{tabular}

${ }^{1}$ In each column, means followed by one or more letterss in common do not differ significantly at the $5 \%$ probability level. Each value represents the mean of 6 plots ( 2 levels of $P$ and 3 replicates).

${ }^{2}$ Adjusted to $15.5 \%$ moisture.

TABLE 5.-Grain yield and other agronomic data for corn varieties in experiment 4 planted April 26 and harvested August 10,1978 (106 days) at Isabela Puerto Rico

\begin{tabular}{|c|c|c|c|c|c|c|c|}
\hline Variety/Source & Lodging & Ear length & Ear weight & Shelling & 100 -seed & Grain $^{2}$ & Stover $\mathrm{DM}^{2}$ \\
\hline & $\%$ & $\mathrm{~cm}$ & g & $\%$ & weight $g$ & $\mathrm{~kg} / \mathrm{ha}$ & $k g / h a$ \\
\hline X5800, Pioneer & $11 \mathrm{~d}$ & $14.3 \mathrm{abc}$ & $180 \mathrm{a}$ & $77 \mathrm{abc}$ & $37.1 \mathrm{ab}$ & $6559 \mathrm{a}$ & $6940 \mathrm{ab}$ \\
\hline X304C, Pioneer & $14 \mathrm{~d}$ & $15.0 \mathrm{a}$ & $168 \mathrm{a}$ & $77 \mathrm{ab}$ & $32.1 \mathrm{bc}$ & $5856 \mathrm{ab}$ & $5888 \mathrm{bcd}$ \\
\hline X306B, Pioneer & $16 \mathrm{~cd}$ & $13.5 \mathrm{bc}$ & $163 \mathrm{ab}$ & $76 \mathrm{bc}$ & $38.2 \mathrm{a}$ & $5654 \mathrm{abc}$ & 6442 abc \\
\hline X304A, Pioneer & $22 \mathrm{~cd}$ & $14.2 \mathrm{abc}$ & $170 \mathrm{a}$ & $75 \mathrm{~cd}$ & $36.7 \mathrm{ab}$ & $5300 \mathrm{bc}$ & $5506 \mathrm{~cd}$ \\
\hline X4817, Pioneer & $26 \mathrm{bc}$ & $14.5 \mathrm{abc}$ & $157 \mathrm{ab}$ & $74 \mathrm{~d}$ & $29.2 \mathrm{c}$ & $5209 \mathrm{bc}$ & 5643 bcd \\
\hline X4816, Pioneer & $37 \mathrm{a}$ & $13.3 \mathrm{c}$ & $140 \mathrm{bc}$ & $74 \mathrm{~d}$ & $29.1 \mathrm{c}$ & $4877 \mathrm{c}$ & 6147 abcd \\
\hline Diente de Caballo, P.R. & $36 \mathrm{ab}$ & $14.8 \mathrm{abc}$ & $141 \mathrm{bc}$ & $78 \mathrm{a}$ & $37.9 \mathrm{a}$ & $4433 \mathrm{~cd}$ & $4937 \mathrm{~d}$ \\
\hline 111, Cargill, Br. & $19 \mathrm{~cd}$ & $14.9 \mathrm{ab}$ & $115 \mathrm{c}$ & $75 \mathrm{~cd}$ & $26.6 \mathrm{c}$ & $3682 \mathrm{~d}$ & $7314 \mathrm{a}$ \\
\hline
\end{tabular}

${ }^{1}$ In each column, means followed by one or more letters in common do not differ significantly at the $5 \%$ probability level. Each value represents the mean of 12 plots (2 levels of $\mathrm{P}, 2$ levels of $\mathrm{N}$ and 3 replicates).

${ }^{2}$ Adjusted to $15.5 \%$ moisture. 
first three experiments also received $90 \mathrm{~kg} / \mathrm{ha}$ of $\mathrm{N}$ as ammonium sulfate. The blanket application of fertilizer, plus all P treatments and $1 / 3$ of the $\mathrm{N}$, was broadcast on the surface and incorporated into the upper $15 \mathrm{~cm}$ of soil with a hand-operated rototiller just prior to planting. The remaining $2 / 3$ of the $\mathrm{N}$ was sidedressed 35 days after planting.

Two to three seed were planted per hill approximately $2-4 \mathrm{~cm}$ deep and $23 \mathrm{~cm}$ apart in rows spaced $75 \mathrm{~cm}$ apart. The sub-plots in experiments 1,2 and 3 and sub-sub-plots in experiment 4 were $2.25 \times 6$ m consisting of 3 rows $6 \mathrm{~m}$ long. At the 4-leaf stage (8) the plants were thinned to 1 per $23 \mathrm{~cm}$ within the rows, equivalent to $57,971 \mathrm{plants} / \mathrm{ha}$.

Weeds were controlled with Lasso ${ }^{4}$ (Alachlor) applied as a preemergent herbicide and later by hand hoeing. Diazinon AG 500, Lannate and Sevin were applied alternately as required for insect control.

All plots were irrigated when necessary according to observations or when readings of tensiometers placed at 15 and $30 \mathrm{~cm}$ depths within selected plots showed 20 centibars tension. Trickle irrigation was applied with Chapin twin-wall tubing with hole spacing of $81 \mathrm{~cm}$ and $20 \mathrm{~cm}$ in inner and outer walls, respectively. By this method water was applied directly to the crop row.

All data were taken from the center 4 linear meters of the middle row in each plot. The following observations were recorded in the field during harvest of the 4-m row: total number of plants, root- and stalk-lodged plants, ears/plot, total ear weight and stover weight. Ear length and weight, grain weight, 100-seed weight, and percent moisture were obtained from a five- or eight-ear sub-sample from each plot. Stover samples taken from eight randomly selected plants were chopped into $2-5 \mathrm{~cm}$ long sections from which 500 sub-samples were dried to constant weights for dry matter (DM) determinations. Grain and stover yields and shelling percentage were calculated from these data. Grain yield is reported as 15.5\% moisture grain and stover yield as DM.

\section{RESULTS AND DISCUSSION}

\section{GRAIN YIELD}

The varieties tested in each experiment are ranked in tables 2, 3, 4 and 5 in descending order according to their grain yield. In the first three trials the Pioneer brand hybrid X304C ranked highest with mean yields of $9,782,3,962$ and $8,998 \mathrm{~kg} / \mathrm{ha}$ of $15.5 \%$-moisture grain. In the fourth experiment the same hybrid produced $5,856 \mathrm{~kg} / \mathrm{ha}$ of grain and ranked

\footnotetext{
${ }^{4}$ Trade names in this publication are used only to provide specific information. Mention of a trade name does not constitute a warranty of equipment or materials by the Agricultural Experiment Station of the University of Puerto Rico, nor is this mention a statement of preference over other equipment or materials.
} 
second but not significantly below X5800 $(6,559 \mathrm{~kg} / \mathrm{ha})$ or above X306B $(5,654 \mathrm{~kg} / \mathrm{ha})$. Hybrid X304B, included in the first three experiments never yielded significantly lower than X304C. Other Pioneer hybrids such as X304A and X306B also ranked high consistently.

Hawaiian hybrids H638, H652 and H788 yielded well in experiment 1 with grain yields of $8,315,8,019$ and $7,659 \mathrm{~kg} / \mathrm{ha}$, respectively. H638 was again included in experiment 2 but was then dropped from further trials as it was excelled by a number of other entries. H610, a prospective testcrop variety for Hawaii-BSP Eutrustox sites, ranked tenth in the first trial and last in the next two experiments. It was the most severely lodged (89\%, table 3) variety and suffered the heaviest attack by leaf rust in experiment 2 when considerable ear damage resulted from the high incidence of broken stalks. For all varieties, lodging was predominantly due to stem breakage except in experiment 1, when root and stalk-lodged plants occurred in about equal proportions.

Diente de Caballo, a locally grown, open pollinated variety, produced fair to good grain yields of $6,966,7,081$ and $4,433 \mathrm{~kg} /$ ha in experiments 1 , 3 and 4, respectively, but always significantly less than the top entries. Another locally important open pollinated variety, Mayorbela, was fourteenth $(6,672 \mathrm{~kg} / \mathrm{ha})$ in the first trial and was thus eliminated from further consideration. Oaxaca, a variety from Mexico selected for phenological observations not reported in this paper, produced $4,670 \mathrm{~kg} / \mathrm{ha}$, the lowest grain yield in the first experiment.

Phoenix IAC 1110, an early choice for UPR-BSP experiments in Brazil, yielded only $2447 \mathrm{~kg} / \mathrm{ha}$, significantly less than the leading six entries in the second variety trial in Puerto Rico. Meanwhile, Cargill hybrid 111 was recommended for use on the BSP site in Brazil. Both of these hybrids yielded well in Brazil, but Cargill 111 ranked intermediate to low in Puerto Rico in experiments 2, 3 and 4 with yields of 2,155, 7,520 and 3,682 $\mathrm{kg} / \mathrm{ha}$, respectively. The Pioneer brand hybrid X304C consistently performed well in BSP variety trials on Eutrustox in Brazil as well as in Puerto Rico and Hawaii and has therefore been selected for use in all subsequent experiments on all Oxisols sites of the BSP network. More recently, however, this hybrid has shown high susceptibility to lodging under the Brazil site conditions.

Varieties responded significantly to the highest $\mathrm{P}$ level only in the first experiment. In all other experiments there were no significant grain yield increases in response to the higher level of $\mathrm{P}$. And there were no significant grain yield response interactions among $\mathrm{P}$ levels and varieties for any of the trials. Grain yield data are therefore shown only as means over both levels of P. On the sites selected for these experiments, even the lower level of $\mathrm{P}$ was sufficient under the prevailing conditions.

Two nitrogen levels, 90 and $166 \mathrm{~kg} / \mathrm{ha}$ of $\mathrm{N}$, were superimposed over 
varieties and $\mathrm{P}$ treatments in the last experiment. Although for each variety, mean grain yield appeared higher where the $166 \mathrm{~kg} / \mathrm{ha}$ rate of $\mathrm{N}$ was applied, a statistically significant response was shown only for X304A, and only the mean values over both levels of each nutrient are shown in table 5. Treatment effects were likely minimized by lateral movement of water and soil during a heavy rain storm soon after seedling emergence. Residual nutrients from previous management also mask possible yield responses that would otherwise be expected on this Eutrustox after a few successive cropping seasons.

Corn grain yields varied sharply from season to season and year to year on the sites utilized. Weather data summarized in table 1 do not show cause for such variation. Grain yields in the second trial were probably restricted by insects and diseases; insect control was not as effective as in other experiments, and all varieties were heavily infested with leaf rust. Lodging was serious throughout the second experiment resulting in damaged ears and further yield reductions.

\section{YIELD COMPONENTS}

Ear lengths, ear fresh-weights, and shelling percentages are shown for all experiments in tables 2, 3,4 and 5. Highest grain yields were generally associated with long and heavy ears, but not all varieties with large ears produced high grain yields. In experiment 1 the highest yielding varieties, X304C, X304B, and X304A also had the heaviest ears with 268, 262 and 275 g/ear, respectively. Variety H507, however, also had heavy ears, 249 g/ear, but ranked eleventh in grain yield. The lowest yielding variety, Oaxaca, had the shortest $(10.2 \mathrm{~cm})$ and lightest $(99 \mathrm{~g})$ ears; these small ears, however, had the highest shelling per cent, $89 \%$, significantly higher than that of all other varieties. The large ears of the first experiment were not equalled in any of the subsequent tests, nor were grain yields. Ear mean weights analyzed in the first experiment were determined from 5 -ear samples, while all of the harvested ears were used for determining mean weights in the last three trials.

In the second experiment, ears were short, 8.4 , to $12.5 \mathrm{~cm}$, and light, 31 to $150 \mathrm{~g} /$ ear, for all varieties. The ear weights in this trial indicate some variety $\times$ P-level interaction, as shown in table 3 , that was not apparent in yields or other yield component data, and is not readily explainable. Shelling percentages also were generally lower in experiment 2 than in the first and third and were similar to those of the fourth experiment. The higher yielding varieties, however, maintained fairly constant shelling percentages throughout the study, even though ear size varied considerably among seasons and years for those varieties.

For the last two experiments (tables 4 and 5), 100-seed weights were obtained. Seed were notably heavier for the third experiment, which also 
yielded much better than the fourth. Diente de Caballo seed were heaviest, $50.3 \mathrm{~g} / 100$ seed, followed by X306B, X304A, X304B and X304C with 100 -seed weights of $48.1,47.5,45.0$ and $44.0 \mathrm{~g}$, respectively, in the third trial. Hawaii H610 and Cargill 111 seed weights were lowest with 34.0 and $31.4 \mathrm{~g} / 100$ seed. Seed weights for the last experiment were much lighter but again led by Diente de Caballo, $37.9 \mathrm{~g}$, and X306B, $38.2 \mathrm{~g}$.

\section{STOVER YIELD}

When grown for forage, the various varieties tested could be expected to rank somewhat differently than when grown solely for grain. Stover yields are shown in tables 2, 3, 4 and 5 . The fairly tall $(322 \mathrm{~cm})$ and slightly slower maturing variety $\mathrm{H} 507$ from Mexico ranked eleventh for grain yield in experiment 1 but first for stover yield with $10,473 \mathrm{~kg} / \mathrm{ha}$ of DM. In contrast, Pioneer's X304C produced 10,200 kg/ha of stover, not significantly less than $\mathrm{H} 507$, and ranked highest in grain yield as well, $9,782 \mathrm{~kg} / \mathrm{ha}$. On the basis of these results, X304C would be an excellent dual purpose hybrid for production of grain only or for silage or greenchop forage. It should be pointed out that the varieties tested were not selected for the purpose of producing high forage yields and their evaluation for forage yield is incidental.

Although the second trial gave low grain yields, stover production was relatively high. The top ranking varieties, IAC Maya X1975, QK217, H638, H507 and QK231 yielded 14,471, 14,120, 13,982, 13,412 and 13,237 $\mathrm{kg} / \mathrm{ha}$ of dry stover, respectively. The Australian hybrid QK231 also ranked well for grain yield as well as stover, among the second group of varieties tested; other high stover yielding varieties of this group were dropped from further trial because of their relatively low grain yields.

Lodging was a serious problem throughout the second experiment and was most severe for $\mathrm{H} 610$, the lowest producer of stover, $6,127 \mathrm{~kg} / \mathrm{ha}$, as well as grain, $962 \mathrm{~kg} / \mathrm{ha}$. All varieties of this second group were also heavily infested with leaf rust; those most severely attacked, QK487, Ag504 and H610, ranked 11th, 15th and 16th, respectively, for stover yield.

In experiments 3 and 4 , varieties were less stratified by forage yields. Out of seven varieties tested in experiment 3 , the five highest yielding ones were similar; only $\mathrm{H} 610$ produced significantly less, 3,936 kg/ha, than the remaining six varieties. Diente de Caballo was next lowest, 7,295 $\mathrm{kg} / \mathrm{ha}$ of dry stover, but significantly lower than only the top yielder, X306B, which gave $9,666 \mathrm{~kg} / \mathrm{ha}$ of DM. In the fourth experiment Cargill's hybrid 111 ranked highest, 7,314 kg/ha, but not significantly higher than the next three, X5800, X306B and X4816, which yielded 6,940, 6,442 and $6,147 \mathrm{~kg} / \mathrm{ha}$ of dry stover, respectively. The five lowest ranking varieties did not differ significantly among themselves in the last trial. 
For forage production on Eutrustox, several hybrids among those tested produced stover and grain yield combinations that demonstrate their suitability for use as silage or green-chop forage crops. The Pioneer hybrids, especially X304 (A, B \& C) and X306B, were consistently good yielders. Cargill's 111 and the Australian hybrid QK231 also showed promise and should be further considered, if forage production is the intended purpose.

\section{RESUMEN}

Cuatro ensayos con variedades de maíz (Zea mays L.) se realizaron en la subestación experimental de Isabela en el noroeste de Puerto Rico, localizada a $128 \mathrm{~m}$ sobre el nivel del mar en la latitud $18^{\circ} 28^{\prime} \mathrm{N}$. En esta región las medias anuales de temperatura mínima y máxima son $18.9^{\circ}$ y $29.4^{\circ} \mathrm{C}$, y la media anual de lluvia es $1,658 \mathrm{~mm}$. El suelo es la arcilla caolínica Coto, con un pH que varía de 5.2 a 6.8 .

El híbrido Pioneer $\mathrm{X} 304 \mathrm{C}$ produjo los rendimientos más altos en tres de los ensayos: $9,782,3,962$ y $8,948 \mathrm{~kg} / \mathrm{ha}$ de grano con $15.5 \%$ de humedad. En el cuarto ensayo le siguió al Pioneer X5800 (6,559 kg/ ha), con $5,856 \mathrm{~kg} / \mathrm{ha}$.

Otros híbridos muy buenos fueron los Pioneer X304A, X304B, X306B y X105A, y los Hawaii H638 y H652.

Aunque el rendimiento de algunos híbridos y variedades locales de polinización abierta fue significativamente más bajo, los de las mejores variedades no difirieron entre si significativamente.

\section{LITERATURE CITED}

1. Badillo Feliciano, J., M. A. Lugo-López and T. W. Scott, 1979. Influence of cultivars, N levels and time on $\mathrm{N}$ application on yields, plant characteristics and leaf composition of corn grown on an Oxisol, J. Agric. Univ. P. R. 63 (3): 273-80.

2. Beinroth, F. H., G. Uehara, J. A. Silva, R. W. Arnold and F. B. Cady, 1980. Agrotechnology transfer in the tropics based on Soil Taxonomy, Adv. Agron. 33.

3. Benchmark Soils Project, 1978. Prog. Rep. 1 (through Dec. 1977). Dep. Agron. Soil Sci., College of Tropical Agric. Univ. Hawaii, and Dep. Agron. Soils, College of Agric. Sci. Univ. P. R.

4. Benchmark Soils Project, 1979. Prog. Rep. 2 (Jan. 1978-June 1979). Dep. Agron. Soil Sci., College of Trop. Agric. and Human Resour., Univ. Hawaii, and Dep. Agron. Soil, College of Agric. Sci. Univ. P. R.

5. Centro Internacional de Maíz y Trigo (CIMMYT), 1972. Results of the first international maize adaptation nursery (IMAN). Information Bulletin No. 7 Oct. 1972.

6. Fox, R. H., Talleyrand, H. and Bouldin, D. R., 1974. Nitrogen fertilization of corn and sorghum grown in Oxisols and Ultisols in Puerto Rico, Agron. J. 66: 534-40.

7. Fox, R. L. and E. J. Kamprath, 1970. Phosphate sorption isotherms for evaluating the phosphate requirements of soils, Soil Sci. Soc. Am. Proc. 34: 902-07.

8. Hanway, J. J., 1971. How a corn plant develops, Iowa State Univ. Spec. Rep. No. 48. June 1971 (Rev.).

9. Sotomayor-Ríos, A., 1979. Performance of twelve corn hybrids and selections on three 
consecutive crops on the same site in the same year, J Agric. Univ. P. R. 63 (2): 17079.

10. Talleyrand, H., R. H. Fox and M. A. Lugo-López, 1976. Nitrogen fertilization of a high yielding white-kernel corn in Oxisols and Ultisols in Puerto Rico, J. Agric. Univ. P. R. 60 (3): 336-43.

11. - and M. A. Lugo-López, 1976. Performance of high yielding corn hybrids Pioneer X-306B and Funk's G-795W at high levels of fertilization in the acid and relatively infertile soils (Ultisols and Oxisols) of Puerto Rico, J. Agric. Univ. P. R. 60 (1): 13234. 